\section{Extension of the known distribution of the genus Herdonia Walker (Lepidoptera: Thyrididae) to the Yeoor Hills, Maharashtra, India}

\section{Dinesh Vigneshwar Valke}

17/34 Vijaynagari Annex, Ghodbunder Road, Thane, Maharashtra 400601, India

Email: dinesh.valke@gmail.com

The Thyridid genus Herdonia Walker occurs from Papua New Guinea (Watson \& Whalley 1986) northwards to China (Hampson 1892) and westwards to the Kumaon Himalaya in the Indian state of Uttarakhand (Smetacek 2008). In India, three species belonging to the genus are known to inhabit a narrow belt along the Himalaya and in northeastern India.

On 19 June 2011, a single specimen of this moth was photographed in Yeoor Hills, Maharashtra $\left(19.243197^{\circ} \mathrm{N}\right.$ \& $72.935463^{\circ} \mathrm{E}$, elevation $100 \mathrm{~m}$ ) along a trail in a semievergreen forest in a part of the Sanjay Gandhi National Park. It was resting on the upper side of a leaf of a low growing plant during the daytime in the manner characteristic of the genus (Image 1). The moth settles with the wings outspread and the forelegs and midlegs extended, so that it rests at an angle of roughly $60^{\circ}$ to the substrate, with the anal angle of the hind wing and the anal angle of the forewing resting against the substrate while the costae of the forewings are held at an angle of roughly $60^{\circ}$ between the verso surfaces.

Date of publication (online): 26 September 2011

Date of publication (print): 26 September 2011

ISSN 0974-7907 (online) | 0974-7893 (print)

Editor: Peter Smetacek

Manuscript details:

Ms \# 02913

Received 13 August 2011

Finally accepted 30 August 2011

Citation: Valke, D.V. (2011). Extension of the known distribution of the genus Herdonia Walker (Lepidoptera: Thyrididae) to the Yeoor Hills, Maharashtra, India. Journal of Threatened Taxa 3(9): 2108.

Copyright: (C) Dinesh Vigneshwar Valke 2011. Creative Commons Attribution 3.0 Unported License. JoTT allows unrestricted use of this article in any medium for non-profit purposes, reproduction and distribution by providing adequate credit to the authors and the source of publication.

Acknowledgements: I thank Ryan Brookes, Mahad, Maharashtra, India for identifying the specimen from the photo, and Peter Smetacek, Bhimtal, Uttarakhand, India for guiding me in documenting this sighting.

\section{OPEN ACCESS | FREE DOWNLOAD}

\section{(c) (1) (4)}

Many of the members of this family are local species, suggesting that they require particular conditions in order to colonise an area. In the Himalaya, members of this genus are usually found in forested areas with heavy rainfall. They are on the wing very briefly during the year and are never found in large numbers.

The present record represents a major extension

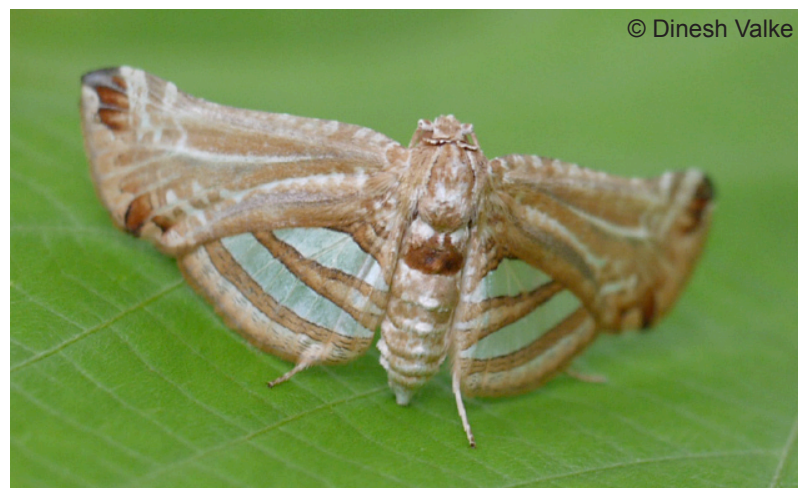

Image 1. Herdonia near thaiensis at Yeoor Hills, Sanjay Gandhi National Park, Maharashtra.

of the known range of the genus, from the Himalayan foothills to the northern Western Ghats. The specimen photographed is placed near Herdonia thaiensis Inoue, although it is not possible to place it with certainty at the species level until at least one specimen is examined.

Since obtaining a specimen will entail special permissions from various protected areas authorities, which, as an individual it will be difficult for the author to obtain and by which time the flying season will certainly be over, the present report is intended to draw the attention of future workers to the presence of this elusive genus in the region.

\section{REFERENCES}

Hampson, G.F. (1892). Fauna of British India including Ceylon and Burma - Moths Vol.1. Dr. W. Junk, The Hague, $23+527 \mathrm{pp}$.

Smetacek, P. (2008). Moths recorded from different elevations in Nainital District, Kumaon Himalaya, India. Bionotes 10(1): 5-15.

Watson, A. \& P.E.S. Whalley (1983). The Dictionary of Butterflies and Moths in Colour. Peerage Books, London, 14+296pp. 